OPEN ACCESS

ISSN 2579-5813 (online)

Edited by: Nurdyansyah

Reviewed by: Amka Amka

*Correspondence:

Agusti Mardikaningsih

agustimardikaningsih@gmail.com

Received: 10 Februari 2021

Accepted: 20 Maret 2021

Published:30 April 2021

Citation:

Mardikaningsih $A$ and Kurniasari $P$ (2021) Developing Blended Learning

Teaching Model through Online Social

Media Platform as Learning's

Support.

Madrosatuna: Journal of Islamic

Elementary School. 5:1.

doi: 10.21070/madrosatuna.v5vi1i.1389

\section{Developing Blended Learning Teaching Model through Online Social Media Platform as Learning's Support}

\author{
Agusti Mardikaningsih ${ }^{1 *}$, Praharisti Kurniasari ${ }^{2}$ \\ Faculty of Exact Science and Sport Education, IKIP Budi Utomo Malang, Indonesia
}

Technology develops rapidly and it affects the technology development at physical, health, and recreation education study program of IKIP Budi Utomo as this year they uses combination learning approach. Students can study anywhere, anytime, and with whomever. To support the current availability of the facilities, the lecturers are required to develop various learning plan models which are easy and comprehensive; one of them is Blended Learning Model. The objective of this research is to develop blended learning model teaching scenario plan and develop blended learning application using social media as the media to ease the teaching and learning process. Online social media were chosen as the basic platform to distribute learning materials and communicate online because of the determinations of usage affordability, effectiveness, and familiarity. The development of blended learning scenario and application used ADDIE Model because it was a general/common learning system model and one of product development models. There is evaluation in each step of ADDIE model. Evaluation is done through validation process and the collected data were analyzed using percentage technique, they are: per item data tabulation and whole data tabulation. Based on the research result, it could be concluded that the percentage of Blended Learning Teaching Scenario developed was considered as appropriate and able to improve the students' comprehension significantly.

Keywords: Development, Blended Learning, Social Media, Sport Students 


\section{INTRODUCTION}

Technology develops rapidly and always changes continuously and it also happens at the campus of IKIP Budi Utomo which is leaving paper-based learning process this academic year. The new students and the lecturer will be supported by gadget. With the available facilities, the lecturers are required to create easy and comprehensive teaching method. Based on the experience and observation conducted by the researchers on teaching and learning design and strategy theories subject on students of Physical, Health, and Sport Education Department at IKIP Budi Utomo, the students tended and were interested in practical subjects while the theoretical subjects were considered as uninteresting. The result of theoretical test of teaching and learning design and strategy subject on the students were not satisfying and far from the expectation. Therefore, the role of lecturers were very important. The lecturers have to be able to act as the good facilitator for the students so that the knowledge transferred was meaningful. Anurrahman (2014)

To transfer knowledge meaningfully, the students should be able to process the received information, re-structured them, and integrated them with the previous knowledge. Meaningful learning is a learning process connecting the new information and the definition structure possessed by a learner. Meaningful learning happens if students try to connect new phenomena to their knowledge structure. It happens through the existing concept learning and concept changes which lead to concept structure growth and change that have been acquired by the students. Technology usingmethod in teaching and learning process is no more a new thing around. Following the development of technology, information, and communication, the teaching and learning innovation and transformation is also required. One of the innovations is blended learning. Blended Learning comes from the words blended (combination) and learning. The original and the most common meaning of blended learning refers to learning process which combines between face-toface learning and computer based learning. According to Thorne (2003), blended learning represents an opportunity to integrate the innovative and technological advances offered by online learning with the interaction and participation offered in the best of traditional learning. The similar meaning is also stated by Bersin (2002) who defined blended learning as the combination of different training "media" (technologies, activities, and types of events) to create an optimum training program for a specific audience. Arif et al. (2002)

Terminology of blended learning is used initially to describe a subject which try to combine face to face learning and online learning. Nowadays, blended learning term is getting popular so that the combination which are referred as blended learning is getting more excessive. However, the definition of blended learning is teaching and learning process which combines the strategy of teaching that integrates face to face activity (offline), computer based teaching, through internet and mobile learning. Azhar (2002)

This research aimed at developing the scenario of teaching and learning model plan of blended learning which was suitable as the teaching and learning support for the students. The objective is also to develop the application through online social media platform as the basis of material distribution and online communication because of program affordability, effectiveness, and reliability considerations

The opinion of Thorne (2003) indicated that blended learning is an integration of multimedia technology, CD ROM video streaming, virtual class, voicemail, e-mail, and telephone conference, online text animation, and video streaming. All of those were combined in the form of traditional trainings in classroom and one by one training. Blended Learning becomes the most suitable solution for teaching and learning process which is not only suitable for students' need but also for the students' learning style.

The importance and significance of blended learning is on the potentials. Blended Learning represents the clear advantages to create learning experience which gives the right teaching and learning process suitable to the era to each individual. Blended learning becomes the universal and global boundary and brings group of students crossing different cultures and time zones. The researchers expect the development of blended learning teaching model will inspire the students to be able to develop their knowledge and curiosity about theory subjects, especially teaching and learning design and strategy. Joyce et al. (2000)

\section{METHOD}

This research is a research and development using ADDIE Model; it is a general teaching and learning system model and one of the models in developing product. Alessi et al. (2001) The implementation of ADDIE model in teaching design facilitates learning environment suitable to the existing problem. Each step in ADDIE model consists of evaluation so that each step will affect the following step. There are 5 steps in ADDIE model. Arikunto (2006)

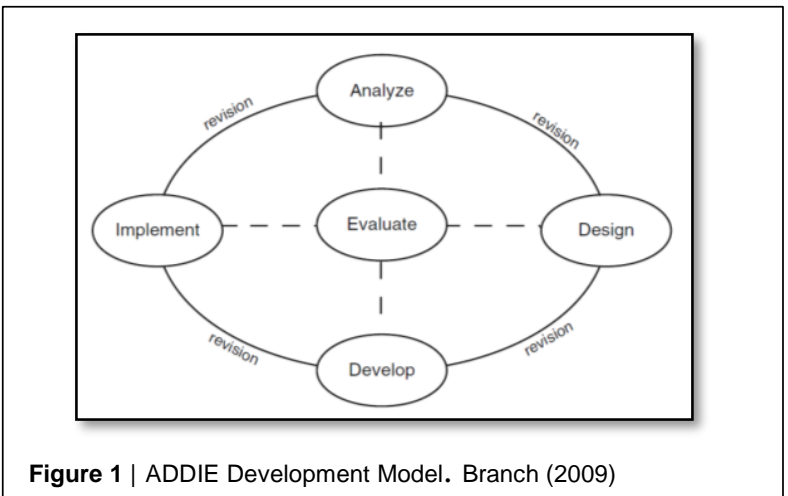

Analyze The objective of this research is to develop blended learning teaching model using online social media platform as the students' learning support. Following the objective of this research, the researchers identify the subject, object, the available learning source, the appropriateness of the characteristics and the competence of the students in model development studied. Analysis is conducted by doing observation, distributing questionnaire, and doing interview with lecturers and students. 
Design The design of this research is the prototype of teaching scenario which is matched to the objective of teaching and learning process. The development of teaching model design of blended learning using online social media platform is designed for students of third semester who have been accustomed to use online media so that this teaching model is expected to construct and train the analytical thinking of the students and also the lecturers.

Develop It is the production step of this research where the prototype has become teaching scenario ready to be used and implemented in teaching and learning process. Allen et al. (2007)

Implement In this step, the teaching scenario and all of the completing elements (application, teaching materials, and teaching scenario) have been ready to be used in teaching and learning process. The activities done are to prepare the lecturers and students to be able to implement them. The objective of the implementation is to lead the students to achieve the learning objectives. a) Blended Learning Development Model Using dengan Social Media Platform

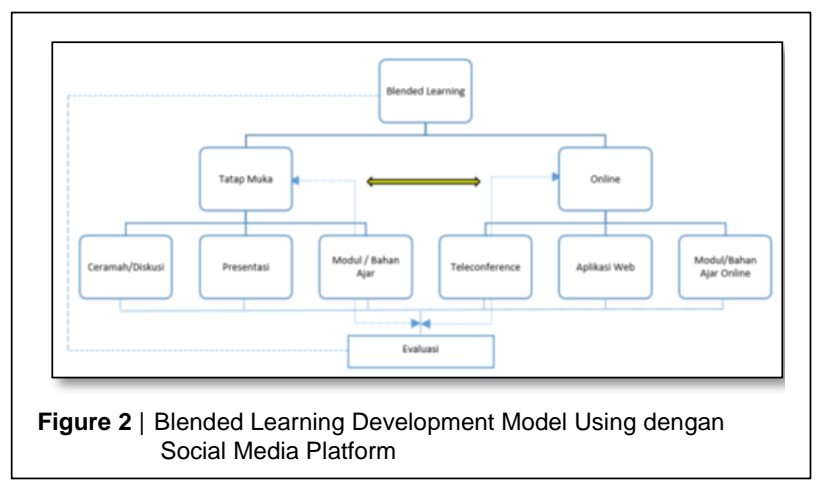

The model above is a model designed based on the needs analyzed before. The basic concept is still on blended learning concept. The difference is the suitable combination used in the chosen subject environment, the option of online and offline teaching and learning suited to the available human resource and the facilities so that the model is expected to be able to be used efficiently; b) Online Aplication



A web learning program on https//belajartanpabatas.com became of the facilities for the students to conduct blended learning teaching model. They could take, watch, and directly interact with the teachers. There were various subjects developed but this research focused on Teaching Design and Strategy subject; c) Blended Learning Teaching Scenario. Here are the activities conducted by the lecturers and the students in sixteen meetings be it face to face or online.

TABLE 1 | Activities Conducted by the Lecturers and the Students in Sixteen Meetings

\begin{tabular}{|c|c|c|c|c|}
\hline \multirow[t]{2}{*}{ Meeting } & \multicolumn{2}{|c|}{ Offline and Face to Face } & \multicolumn{2}{|c|}{ Online } \\
\hline & $\begin{array}{l}\text { Teaching } \\
\text { Activity }\end{array}$ & $\begin{array}{l}\text { Teaching } \\
\text { Material }\end{array}$ & $\begin{array}{l}\text { Teaching } \\
\text { Activity }\end{array}$ & $\begin{array}{l}\text { Teaching } \\
\text { Material }\end{array}$ \\
\hline 1 & $\begin{array}{l}\text { Having } \\
\text { Course } \\
\text { Contract } \\
\text { Agreement } \\
\text { and } \\
\text { Preliminary } \\
\text { Test }\end{array}$ & $\begin{array}{l}\text { Syllabus, } \\
\text { Teaching } \\
\text { Scenario, } \\
\text { Powerpoint } \\
\text { Slides }\end{array}$ & $\begin{array}{l}\text { Having } \\
\text { Course } \\
\text { Contract } \\
\text { Agreement } \\
\text { and } \\
\text { Preliminary } \\
\text { Test }\end{array}$ & $\begin{array}{l}\text { Syllabus, } \\
\text { Teaching } \\
\text { Scenario, } \\
\text { Powerpoint } \\
\text { Slides }\end{array}$ \\
\hline $2-6$ & $\begin{array}{l}\text { Describing } \\
\text { Material } \\
\text { (Face to Face } \\
\text { and } \\
\text { Discussion) }\end{array}$ & $\begin{array}{l}\text { Module, } \\
\text { LCD, } \\
\text { Powerpoint } \\
\text { Slides }\end{array}$ & $\begin{array}{l}\text { Students } \\
\text { Download } \\
\text { the } \\
\text { Materials, } \\
\text { Answer the } \\
\text { Questions, } \\
\text { Having } \\
\text { Direct } \\
\text { Experiences, } \\
\text { and } \\
\text { Lecturers } \\
\text { Assess } \\
\text { through } \\
\text { Email }\end{array}$ & E-Module \\
\hline $7-9$ & $\begin{array}{l}\text { Course } \\
\text { Review }\end{array}$ & $\begin{array}{l}\text { Presented by } \\
\text { Reviewing } \\
\text { Module } \\
\text { Materials } \\
\text { through } \\
\text { Discussion } \\
\text { and Question } \\
\text { and Answer } \\
\text { Session }\end{array}$ & $\begin{array}{l}\text { Students } \\
\text { Download } \\
\text { the Material } \\
\text { Answer } \\
\text { Review }\end{array}$ & $\begin{array}{l}\text { Materials } \\
\text { Review }\end{array}$ \\
\hline 10 & $\begin{array}{l}\text { Oral Mid-term } \\
\text { Test }\end{array}$ & $\begin{array}{l}\text { Mid-term } \\
\text { Test } \\
\text { Question } \\
\text { Items }\end{array}$ & $\begin{array}{l}\text { Oral Mid- } \\
\text { term Test }\end{array}$ & $\begin{array}{l}\text { Mid-term } \\
\text { Test } \\
\text { Question } \\
\text { Items }\end{array}$ \\
\hline $11-15$ & $\begin{array}{l}\text { Describing } \\
\text { the Materials } \\
\text { (Face to Face } \\
\text { and } \\
\text { Discussion) }\end{array}$ & $\begin{array}{l}\text { Module, } \\
\text { LCD, } \\
\text { Powerpoint } \\
\text { Slides }\end{array}$ & $\begin{array}{l}\text { Students } \\
\text { Download } \\
\text { Materials, } \\
\text { Answer the } \\
\text { Questions, } \\
\text { Having } \\
\text { Direct } \\
\text { Experience, } \\
\text { and } \\
\text { Lecturers } \\
\text { Assess } \\
\text { through } \\
\text { email }\end{array}$ & E-Module \\
\hline 16 & Final Test & $\begin{array}{l}\text { Final Test } \\
\text { Question } \\
\text { Items }\end{array}$ & Final Test & $\begin{array}{l}\text { Final Test } \\
\text { Question } \\
\text { Items }\end{array}$ \\
\hline
\end{tabular}

Evaluate Evaluation was done through the process of blended learning model design validation which was conducted by the experts of media, material, and the students who were divided into small groups, big groups, and individual. The instrument used in the process of validation was in the form of closed instrument or questionnaire. While the collected data were analyzed using percentage technique. Data tabulation was per item and wholly. The evaluation criteria was an adaptation from Arikunto assessment criteria. If the result attained from try-out reached the score of $60 \%$, the developed blended learning model design can be developed further. Rusman (2015)

In calculating the data of development questionnaire per item decided the assessment as below:

Answer $\mathrm{A}=4, \mathrm{~B}=3, \mathrm{C}=2, \mathrm{D}=1$

The formula used were:

1) Calculating data per item 


$$
P=\frac{X}{X i} \times 100 \%
$$

Description:

$\mathrm{P}=$ Percentage

$\mathrm{X}=$ Respondent's answer in an item

$\mathrm{Xi}=$ Ideal score number in an item

$\%=$ Constanta

2) Calculating data as a whole

$$
\begin{aligned}
P & =\frac{\sum X}{\sum x i} \times 100 \% \\
\text { Description: } & \\
\mathrm{P} \quad & =\text { Percentage } \\
\sum \mathrm{X} & =\text { Respondent number } \\
\sum \mathrm{Xi} & =\text { Score whole number in an item } \\
\% \quad & =\text { Constanta }
\end{aligned}
$$

After the result of the data tabulation was attained using the formula above, the result was matched to the criteria of media usage feasibility as follows:

Table. Feasibility Level Criteria (Bambang, 2009:53)

\begin{tabular}{cccc}
\hline Category & Percentage & Qualificatin & Equivalence \\
\hline A (4) & $80 \%-100 \%$ & Valid & Feasible \\
B (3) & $60 \%-79 \%$ & Fair & Fair \\
C (2) & $50 \%-59 \%$ & Less Valid & Less Feasible \\
D (1) & $0 \%-49 \%$ & Invalid & Not Feasible \\
\hline
\end{tabular}

\section{RESULT AND DISCUSSION}

To test the feasibility of blended learning teaching model, the researchers did validation test by content/material and media validators. Validation was done using closed instrument/questionnaire. Material validator was the lecturer of Teaching Design and Strategy subject. This validation was done to examine whether or not the developed product was feasible to be implemented. The result of percentage given by the material expert was $88.05 \%$ with the equivalence of feasible to be implemented but there were several revision required. Semler (2005)

Media validator was an Education Technology lecturer. This validation was to examine whether or not the blended learning application design and the teaching scenario were valid and feasible to be developed. The result of validation outcome percentage using instruments was $85.75 \%$ with the equivalence of feasible and valid qualification.

Try-out was conducted three times during 16 meetingteaching and learning process individually, in groups of three, and in groups of six. From each percentage, the results were $82.25 \%$ with the equivalence of feasible and valid qualification for the small group and $90.25 \%$ with the equivalence of feasible and valid qualification for individual so that it can be concluded that the development of teaching model, application, and scenario was feasible to be implemented and able to improve learning motivation, students' analysis in teaching and learning design and strategy theory. This result is in line with the opinion of Aunurrahman (2014) who said that teaching model development aims at growing and increasing students' learning motivation so that they will not be bored with the teaching and learning process. In addition, the efficiency level of blended learning model could also be seen from the decreasing time of teaching and learning process activities. The duration of each learning process activity was shorter compared to the classical teaching and learning process.

\section{CONCLUSION}

The results of this study can be concluded that the level of efficiency of the blended learning model can also be seen from the reduced time for teaching and learning activities. The duration of each learning process activity is shorter than the classical teaching and learning process. In addition, it can also be concluded that the percentage of the Blended Learning Teaching scenario developed is appropriate and able to significantly increase student understanding.

\section{REFRENCES}

AECT. 2004. AECT Definition and Terminology Committee Document: The Meanings of Educational Technology.

Alessi, SM and Trollip, SR. 2001. Multimedia for Learning: Methods and Development. (3rd Ed). Boston MA: Allyn and Bacon, Inc.

Allen, IE, Seamen, J. \& Garret, R. 2007. Blending in: The Extent and Promise of Blended Education in the United States. USA: The Sloan Consortium.

Arif S, Sadiman. et. al. 2002. Media Pendidikan, Pengertian, Pengembangan dan Pemanfaatannya. Jakarta: Raja Grafindo Persada.

Arifin,Zainal.2012. Evaluasi Pembelajaran (Prinsip, Teknik, Prosedur): PT Remaja Rosdakarya

Arikunto, Suharsimi. 2006. Prosedur Penelitian Suatu Pendidikan dan Praktik Jakarta: PT Rineka Cipta

Arsyad, Azhar. 2002. Media Pembelajaran Jakarta:PT Raja Grafindo Persada

Ary, D.; Jacobs, L. C.; Razavieh, A. 1982. Introduction to Research in Education. (Terjemahan Arief Furchan). Surabaya: Usaha Nasional.

Aunurrahman. 2014. Belajar dan Pembelajaran. Bandung:Alfabeta

Baturay, M.H. \& Yukselturk, E. (2015). The role of online education preferences on student's achievement. Turkish Online Journal of Distance Education, 16(3), 312.

Branch, RM. 2009.Intructional Design: The ADDIE Approach: Department of Degeng, I.N.S. Landasan Teoritik Desain Pembelajaran. Malang: Fakultas Pascasarjana IKIP Malang

Dziuban, C,H Joel L. Hartman Patsy D. Moskal 2004, Blended Learning Research Bulletin7, 1-12 Environment Conference Proceedings, Universityof Salford, Salford: Education Development Unit.

Educational Psychology and Instructional Technology University of Georgia

Joyce, B., \& Marsha, W. (2000). Models of Teaching. Amerika: A. Pearson Education Company.

Mortera-Gutierrez, F. J. (2006). Faculty best practices using blended learning in e-learning and face-to-face instruction. International Journal on E-Learning, 5, $313-337$

Oravec, J. (2003). Blending by blogging: Weblogs in blended learning initiatives. Journal of Educational Media, 28, 225-233.

Osguthorpe, R., \& Graham, C. (2003). Blended learning environments. Quarterly Review of Distance Education, 4, 227-233

Rusman. (2015). Model-Model Pembelajaran: Mengembangkan Profesionalisme Guru. Jakarta: Raja Grafindo Persada.

Semler, S. (2005). Use Blended Learning to Increase Learner Engagement and Reduce Training Cost. Retrieved from http://www.learningsim.com/content/lsnews/blended_learning1.html

Sharpe, R., Benfield, G., Roberts, G., \& Francis, R. (2006). The undergraduate experience of blended e-learning: A review of UK literature and practice. Retrieved

fromhttp://www.heacademy.ac.uk/assets/York/documents/ourwork/archive/bl ended_elearning_Full_review.pdf

Sue-Jen Chen. 2007. Instructional Design Strategies for Intensive Online Courses: An Objectivist-Constructivist Blended Approach. Volume 6, Number 1, Spring 2007.

Uno, Hamzah B., Perencanaan Pembelajaran, 2006, Bumi Aksara PT: Jakarta

Whitelock, D., \& Jelfs, A. (2003). Editorial: Journal ofEducational Media Special Issue on Blended Learning. Journal of Educational Media, 28(2-3), 99-100. https://doi.org/10.1080/1358165032000177407. 
Conflict of Interest Statement: The authors declare that the research was conducted in the absence of any commercial or financial relationships that could be construed as a potential conflict of interest.

Copyright (C) 2021 Ndari, Masyukoh, Vinayastri, and Kibitiah. This is an openaccess article distributed under the terms of the Creative Commons Attribution
License (CC BY). The use, distribution or reproduction in other forums is permitted, provided the origi-nal author(s) and the copyright owner(s) are credited and that the original publication in this journal is cited, in accordance with accepted academic practice. No use, distri- bution or reproduction is permitted which does not comply with these terms 